\title{
Article
}

\section{Visualizing Faith and Futility in the Nuclear Apocalypse}

\author{
Alison Fields
}

Citation: Fields, Alison. 2022 Visualizing Faith and Futility in the Nuclear Apocalypse. Religions 13: 142. https://doi.org/10.3390/ rel13020142

Academic Editors: Yuki Miyamoto and Susumu Shimazono

Received: 22 November 2021

Accepted: 29 January 2022

Published: 3 February 2022

Publisher's Note: MDPI stays neutral with regard to jurisdictional claims in published maps and institutional affiliations.

Copyright: (C) 2022 by the author. Licensee MDPI, Basel, Switzerland. This article is an open access article distributed under the terms and conditions of the Creative Commons Attribution (CC BY) license (https:// creativecommons.org/licenses/by/ $4.0 /)$.
Department of Art History, University of Oklahoma, Norman, OK 73019, USA; afields@ou.edu

\begin{abstract}
This paper explores the intersection of personal responsibility, futility, and faith in visual representations of nuclear apocalypse. In two films produced during the late Cold War, Testament (1983) and When the Wind Blows (1986), the protagonists attempt to follow public guidance, maintain daily routines as their health and communities break down, and make muddled connections to religious faith. In Testament, a mother is left to care for her children in suburban California for months after an unexplained nuclear attack isolates and contaminates the town. In When the Wind Blows, a retired couple living in the British countryside diligently follow government instructions to "protect and survive", while quickly succumbing to radiation poisoning. In a contrasting post-Cold War visual representation, the speculative artwork of the artists Erich Berger and Mari Keto imagine the storage of nuclear waste as a personal responsibility. In Open Care (2016), waste is encased in steel pellets mounted on a bronze disc, and a series of artifacts and instructions assist in determining continued toxicity. While Testament and When the Wind Blows project the futility of personal responsibility and faith in nuclear survival, Berger and Keto's system envisions a deep nuclear future requiring continued personal management and care.
\end{abstract}

Keywords: atomic bomb cinema; Cold War; atomic art; apocalyptic narratives; religion and the atomic age

\section{Introduction}

By imagining the experience of nuclear disaster, filmmakers and artists visualize the ways that people find structure and meaning in the face of an annihilating event. In two films produced during the late Cold War, Testament (1983) and When the Wind Blows (1986), the protagonists attempt to follow public guidance, maintain daily routines as their health and communities break down, and make muddled connections to religious faith. In Testament, based on the short story "The Last Testament" by Carol Amen and directed by Lynne Littman, a mother is left to care for her children in suburban California for months after an unexplained nuclear attack isolates and contaminates the town. In When the Wind Blows, the 1982 graphic novel by British artist Raymond Briggs, adapted to film by American animator Jimmy Murakami in 1986, a retired couple living in the British countryside diligently follow government instructions to "protect and survive", while quickly succumbing to radiation poisoning. The two films offer no real leadership or promise for salvation, but rather emphasize the quiet futility of personal responsibility and faith in the face of overwhelming disaster.

In a contrasting post-Cold War visual representation, the speculative artwork of the artists Erich Berger and Mari Keto imagines the storage of nuclear waste as a shared personal responsibility. In their proposed system in Open Care (2016), displayed reverently as a shrine, waste is encased in steel pellets mounted on a bronze disc, and a series of artifacts and instructions assist in determining continued toxicity. While Testament and When the Wind Blows project the futility of personal responsibility and faith in nuclear survival, Berger and Keto's system, to be passed down over generations, envisions a deep nuclear future requiring continued personal management and care.

The films and artwork, taken together, run counter to traditional religious apocalyptic narratives, with no divine force guiding events or assigning judgement. Instead, by 
depicting efforts to maintain a family unit, build a shelter to government specifications, and manage radioactive waste, they demonstrate the intersections of personal responsibility, futility, and religious faith in visual representations of nuclear apocalypse. Specifically, I argue, Littman and Murakami's narrative films underscore the impossibility of effectively responding to a nuclear disaster after it occurs and demonstrate the danger of complacency and deferred action in facing nuclear threats. Rather, as Open Care imaginatively suggests, the global problem of managing nuclear capabilities remains urgent decades after the Cold War and can only be countered through pre-emptive and sustained shared responsibility.

\section{Atomic Bomb Cinema in 1980s}

Beginning in 1981, Ronald Reagan's presidency amplified Cold War rhetoric as military spending surged to support continued arms development and tensions rose with the Soviet Union. In By the Bomb's Early Light, originally published in 1985, historian Paul Boyer notably argued that nuclear themes re-emerged in film and television in the 1980s, as part of cyclical responses to the bombings (Boyer 1985, pp. x-xi). The cycles return with the advent of new nuclear technologies or the escalation of wartime conflicts. However, in The Rise of Nuclear Fear, Spencer Weart suggests that the fear of nuclear weapons never truly dissipated. He writes: "Why did anxiety about nuclear war emerge again around 1980? There may be a cycle to such things, as the exhaustion of fruitless anxiety wears off. But there were direct causes. Citizens usually responded rapidly to new facts about weapons, and there were dreadful new facts" (Weart 2012, p. 230). Specifically, Weart points to the United States' rapid multiplication of nuclear warheads in the late 1970s, matched by the Soviet Union in the early 1980s (Weart 2012, p. 230). In 1982, Jonathan Schell's essay The Fate of the Earth became the first nonfiction book about nuclear war to become a best-seller since John Hersey's 1946 Hiroshima (Weart 2012, p. 230). Furthermore, as social programs were cut and many Americans faced increased financial pressures, a combination of factors led to a generalized feeling of insecurity (Shapiro 2001, p. 182). Antinuclear activism rose in response, reaching a height by the mid-1980s.

The public often comes to understand contemporary social anxieties, phobias, and catastrophes through the lens of mass media and narrative film. Further, the narrative of the apocalypse is a common lens for representing contemporary life-threatening disasters (Ritzenhoff and Krewani 2016, p. xii). Emerging in Jewish and Christian literature beginning 200 BCE, and expressed in the biblical books of Daniel, Ezekiel, and John's Revelation, the apocalypse tells the story of God's final judgment and destruction of the earth (Ostwalt 2009, p. 365). As the seven seals of the apocalyptic book are opened, a series of plagues unfold, leading to God's final "condemnation of sinners and resurrection of the good" (Ritzenhoff and Krewani 2016, p. xii). This dualistic separation, Conrad Ostwalt writes, is underscored by the "assertion and promise of God's ultimate and final sovereignty, and it is divine intervention into the apocalyptic drama that allows the end of history to be meaningful." Without God's intervention, it is presumed, the end of the world results in nihilism (Ostwalt 2009, p. 365).

The narrative of the apocalypse has endured as an allegory for understanding current threats. As Karen Ritzenhoff and Angela Krewani write in The Apocalypse in Film, "The religious apocalypse provides a structure to express our fear of an ending and to give expression to politically threatening situations that we could not understand otherwise" (Ritzenhoff and Krewani 2016, p. xii). Over time, the narrative of apocalypse has taken on secular meanings, with God's role in earth's destruction gradually subsumed by modern technology and man-made conditions, such as nuclear weapons, viruses, or global warming. In these secular narratives, there is no distinction between how the apocalypse will impact the good or the sinners - all of humanity is at risk (Ritzenhoff and Krewani 2016, p. xii). While these narratives may include religious themes or imagery, without the element of divine justice, Oswalt argues, such narratives are not traditionally apocalyptic (Ostwalt 2009, p. 369). Instead of a fatalistic acceptance of the end of the world as part of God's plan, in secular apocalypse narratives, emphasis is placed on human survival and heroism. Yet, even 
in secularized representations of the end of the world, there is often an effort to ascribe meaning to catastrophe.

The visually rich narrative of the apocalypse translates especially well into film and has served as the primary structure for atomic bomb cinema (Shapiro 2001, pp. 5-6). Film scholar Jerome Shapiro defines atomic bomb cinema as "films where the bomb is an explicit part of the mise-en-scène (the set or environment), theme, context, and /or the narrative" (Shapiro 2001, p. 10). Such films-which may address nuclear weapons, fallout, or terrorism - cross multiple genres, and are only bound together by "distinct, recurring themes" (Shapiro 2001, p. 12). In the 1980s, a number of Hollywood films about nuclear disaster glorified the military establishment and emphasized heroic survivors facing postnuclear holocausts (Evans 1998, p. 174). In films such as The Terminator (1984), Future Hunters (1985), and The Survivor (1988), film scholar Joyce Evans writes, "the surviving hero is confronted with a frontier to conquer, a civilization to rebuild, and a post-nuclear war environment unsullied by the effects of radiation or nuclear winter" (Evans 1998, p. 175). Hollywood filmmakers returned to familiar depictions of nuclear issues, developed in the first decades after the atomic bombings of Japan. By replicating earlier formulas, nuclear war is shown to be survivable, and the agent for new social possibilities. Evans writes, "Conceiving of a nuclear confrontation as inevitable and portraying the lucky survivors' daily existence as exciting and attractive promotes the idea that the American nuclear policy is 'natural,' 'right,' and acceptable, an inevitable product of nature rather than of history" (Evans 1998, p. 176). These films enforced secular apocalypse narratives, where the military and social system could triumph against man-made catastrophes.

However, as Shapiro points out, atomic bomb cinema has never reflected a singular ideology (Shapiro 2001, p. 192). The early to mid-1980s saw "seemingly contradictory cultural developments in the U.S." that led to both an embrace of and fear of the Reagan platform. As a result, other atomic bomb films of the decade convey the darker outcomes of a nuclear attack (Shapiro 2001, p. 210). Concerned that new generations would "forget" the reality of atomic trauma, ABC television promoted their 1983 film The Day After as a news event, drawing 100 million viewers (Weart 2012, p. 233). Intended as a critique of heightened arms development, The Day After imagined the lead-up and aftermath of a Soviet strike, with the primary focus on a small midwestern town. While the film was notable for its graphic depictions of mushroom clouds and radiation burns, functional U.S. government and military operation is shown to withstand limited nuclear war (Evans 1998, p. 174). Other films turned more strongly from earlier structures and emphasized human inability to understand or survive a nuclear attack. In Testament, the quest for human survival after nuclear attack is not imbued with broader meaning. While the film points to JudeoChristian traditions, religious faith is shown to be inadequate in the face of all-consuming nuclear trauma.

\section{Testament}

Lynne Littman's 1983 made-for-television film, Testament, broke dramatically from uplifting or exciting heroic narratives. As Shapiro points out, in depicting a nuclear attack, Testament does not rely on special effects, or supernatural beings, or grand revelations, "just the catastrophic events of the apocalypse, the illness and suffering and death" (Shapiro 2001, p. 191). Adapted to screen by John Sacret Young, the film was first produced for the Public Broadcasting System's (PBS) American Playhouse series. The success of the film led to its rerelease in theaters and an Oscar nomination for Jane Alexander, who played the leading role of Carol Wetherly (Shapiro 2001, p. 183). Amen's brief short story, published in 1981, begins in Wetherly's voice, "If I sound calm as I begin this, I'm not. Numb would be more like it. Drained, nearly hopeless. I'm writing to try hold on to my sanity. It's something to do, a discipline. I will make every effort to tell what happened, no matter how painful the telling is" (Amen 1981, p. 72). Through her writing, Carol gives testament, or provides evidence, of the disaster that occurred. The term testament also refers to a statement of belief or conviction and designates the two major portions of the Bible. 
The film Testament echoes Carol's tone of drained hopelessness and her fraught efforts to take any sort of action. The film traces Carol's experience of an unexpected and unexplained nuclear attack, which separates her from her husband, Tom, and leaves her to care for their children, elementary-school aged Scottie, and teenagers Mary Liz and Brad, in the fictional Bay Area suburb of Hamelin. The film opens on a routine day in the Wetherly household, with the camera panning over a sunny open window, children's drawings, a cassette player, and family photographs, with a Jane Fonda workout playing in the background. Through hectic family encounters, minor events flag Tom's high expectations of Brad, and his disregard for Carol, as she takes on the bulk of family and household maintenance.

While Tom is at work in San Francisco, and the three children are watching cartoons, the television's reception suddenly falters. A broadcaster from San Francisco suddenly breaks onto the screen, announcing that they have lost their New York signal after radar detected "the explosion of nuclear devices there, in New York, and up and down the East Coast". Assuring viewers, "this is real," another break in programming declares a national emergency, to stay off telephones, and that instructions would follow. Before the president can give any directive, and Carol can answer a phone call presumably from Tom, the screen cuts out, sirens blare, and blinding light pours through the windows. Carol ushers the children into a duck and cover position, and the scene cuts to the immediate aftermath, with neighbors pouring on to the street, crying and screaming.

After the unexplained bombing, neighbor Henry Abhart attempts to make radio contact with other cities. He finds responses only in the Midwest, suggesting that both coasts along with major interior cities have been destroyed. Soon, the community gathers in church. A close-up of a Christ figure, crucified on a cross, is overlaid with noisy, demanding voices, contesting attempts at order. A priest, the police chief, and the mayor take questions that cannot be answered, and respond to concerns of looting and property damage. A doctor points out that they do not have the necessary equipment to measure levels of radioactivity, while a school official notes the need to carry on as normal. As the crowd becomes increasingly agitated, the priest comments, "This isn't getting us anywhere. The reason why we have come here today is to work together, to make this community work". Beyond one call for a community aid force, his words seem to have little impact on the frustrated group. Tempers continue to flare, and in the community, long lines develop at the gas station and for food distribution. In the immediate panic following the bombings, religious faith does not appear to offer meaning or relief to the townspeople. In fact, the initial community meeting suggests that sources of authority-stemming from religion, government, and education - will be equally unable to address the scale of the disaster that has occurred.

Carol begins a journal entry (a device used to track time through the film) on February 24, noting, "Nothing seems real. Everything looks the same". Perhaps because of that unreality, Carol continues guiding her children through daily routines. Seemingly paralyzed by the possibility of leaving Hamelin, Carol takes no action and simply presses on, hoping for Tom's return. As the opening to Amen's short story suggests, Carol's actions seem to come from a sense of discipline, the desire to have "something to do". Carol's attempts to continue with some semblance of normalcy after the bombing, while cast as a noble effort, are an exercise in futility. Mary Liz continues to take piano lessons, while Brad tries to help Mr. Abhart. Carol, who was directing the school play "The Pied Piper of Hamelin" before the bombing, goes forward with the play's production. The inclusion of this play, the inspiration for film's fictional town name, is significant. "The Pied Piper of Hamelin", a famous poem by Robert Browning with origins in medieval folklore, has been reenacted in theater, television, and film. It tells the story of the German town of Hamelin, whose mayor hires a magical Piper to rid itself of a plague of rats. When the town does not pay the Piper for his services, the Piper returns and hypnotizes the town's children, leading them away from Hamelin forever. In Testament's school play, a child recites "Your children are not dead. They will return. They're just waiting till the world deserves them". However, the film 
offers little promise of return. Instead, the play's presence in Testament reinforces a sense of failure and futility-on the part of the town leadership, and in the danger of relying on a magical solution to a problem.

Despite efforts to continue daily activities, warning signs of radiation illness, hopelessness, and death begin to mount. In one early scene after the bombing, the family sits down to breakfast as the power outage starts to spoil their food. Scottie and Mary Liz notice that their plates have dirt on them, and they realize that the food they are eating is likely contaminated. After the school play, parents in the audience break down in tears. A neighbor couple decides to leave Hamelin after the death of their newborn. In a far more somber second meeting at the church, the priest announces that public services would cease, hospital were strained, and burials should be done carefully. The police chief sobs as he insists, "order will be maintained".

Over the course of the film, the town experiences more and more deaths, and Carol takes in two orphaned children, one of whom dies. As it becomes clear that Tom will not return, Carol must bury both Scottie and Mary Liz, creating handmade shrouds for her children, while increasingly fighting the effects of radiation herself. The priest, Hollis, appears intermittently through the film, helping Carol locate Scottie when he runs away and, not long after, leading his burial service. Hollis's demeanor grows increasingly weary, as he is overwhelmed by the need around him. As Shapiro writes, "hope no longer includes God. In both The Day After and Testament, priests try to maintain a façade but it's clear that they have lost their faith" (Shapiro 2001, p. 189). Nearing the end of the film, as the town's green space has been entirely overtaken by graves, a man suddenly embraces Carol from behind. She turns and shares a kiss with Hollis, a move made for comfort and desperation. Hollis, who could not offer religious explanations for what has occurred, has become a source of material and physical aid.

A cut to a Super- 8 style home movie marks each family member's death, and the film concludes with a video of one of Tom's birthdays before the screen cuts to black. While Testament seemingly celebrates the strength of family and community, it also depicts a total lack of power or agency in addressing the bombing and taking any steps beyond the most immediate needs for survival.

\section{When the Wind Blows}

While film scholars have examined Hollywood cinema as an expression of Cold War anxieties, less focus has been placed on international films. For instance, Neal McCrillis points out that Britain had the world's second highest production of Cold War films, offering insight into British skepticism of nuclear weaponry and American foreign policy in the immediate post war period (McCrillis 2002, p. 43). In contrast to Hollywood's glorification of military prowess and emphasis on Communist threats, British science fiction films of the 1950s reflected a sense of unease over superpower domination and advancing technology (McCrillis 2002, p. 46). The sense that science was altering the natural order was often reflected in Judeo-Christian terms, using biblical references, and carried over to British literature (McCrillis 2002, p. 48). As the Cold War intensified again in the 1980s, the 1982 graphic novel by British artist Raymond Briggs, When the Wind Blows, reflected on the themes of vulnerability and the shortcomings of human agency. Adapted to film by American animator Jimmy Murakami in 1986, the dialogue and aesthetic of the graphic novel is kept intact. In both versions, religious faith is presented as a last resort once all efforts for survival are exhausted.

The film starts in live action, with police motorcycles, military vehicles, and cars, and a brief scene of hugging on the street. The scene of emergency fades into an animated newspaper, with headlines declaring an East/West confrontation and more hospital closures. Jim is at the library, sighing at the news, before taking the bus home on a journey through the countryside. He is greeted by his wife Hilda, and while lamenting that his life is not very "fast moving or dynamic", he describes the need to stay abreast of the "international situation". As Jim tries to tell Hilda about a possible preemptive strike, with war breaking 
out at any moment, Hilda repeatedly brushes off his concern. Busily preparing supper as they tune into dire news from the prime minister on the radio, Hilda concludes, "Well, we survived the last one, we can do it again. It'll take more than a few bombs to get me down". In hearing the confirmation of impending war, Jim comments on how lucky he is to have retrieved two "authoritative" pamphlets printed by the city council at the library that morning- "Protect and Survive" and "The Householder's Guide to Survival." Over treacle tart, Jim suggests that they begin building a fallout shelter immediately. Following "modern scientific methods," Jim describes, "You just use doors with cushions and books on top." Hilda responds skeptically, "You don't mean off our own house?"

In building the shelter, Jim must disregard the confusion and skepticism of others about the process. Hilda's logical question about removing the doors of the home in advance of a nuclear attack, and her concern about the damage he is doing to their home, is met with Jim's insistence that the step is part of the guidelines: "I expect it's a safety precaution-it will let the blast go straight through". As Jim stumbles through the process of finding the correct angle for the doors, he is frustrated by a phone call with his son, who clearly thinks Jim is overreacting to the threat and is not making any preparations for his own family. Taken aback, Jim questions, "You mean you're not constructing an inner core or refuge? I gave you the leaflets especially. But what about Baby Jim?" Jim views the construction of the shelter, and following public directives more broadly, as a duty and responsibility. Like Carol Wetherly, it gives him "something to do". In addition to serving as a physical place to go during the bombing, the creation of the shelter gives Jim a sense of purpose and an unshakable (even when the evidence points otherwise) confidence that they will survive. As he repeatedly tells Hilda, they are doing "the correct thing". However, as cultural studies scholar Solvejg Nitzke points out, what seem like necessary precautions for surviving a world-ending event can easily be viewed as paranoia to others. She writes, "But isn't it careless not to prepare? How does one reach the decision to start preparing for the worst? Who is to decide what lies ahead and which safety measures are to be taken?" (Nitzke 2016, p. 81).

In fictional narratives of catastrophe, Nitzke writes that most protagonists succeed in building or locating a shelter that allows for their survival. In creating such narratives, "shelter fiction turns the ultimate unknown into something that seems familiar" (Nitzke 2016, p. 79). By premeditating disaster and taking action that ensures survival, such fiction provides a way to take control of unknowable, unstructured disasters. For those in positions of authority, Marita Sturken writes, "The selling of preparedness is not simply selling the idea that one can prepare for particular adverse situations; it has broader implications, since it sells the comforting idea that one can actually be prepared for the unpredictability of life and, by implication, that life is not arbitrary" (Sturken 2007, p. 71).

Throughout When the Wind Blows, both Jim and Hilda contrast their current war preparations with their experiences in World War II. Hilda nostalgically recalls her childhood bomb shelter, covered in flowers, and Jim recalls sleeping in his shelter, looking at pin-up girls on the wall. They think fondly of Churchill, Roosevelt, and Stalin-"all good blokes". In the present, the Soviet Union has become an enemy, and the wartime threat feels impersonal and abstract. Hilda comments, "I expect it is all done by committees, dear". As war mechanisms become more difficult to understand, Jim holds on to the basic faith that emergency procedures will save them.

After the bombing occurs, to howling winds and a yellow sky, with their red walls fading to grey tones, it first appears that their shelter has sustained them. By the second day, however, they feel tired and achy, and they have no water, electricity, or radio contact. As they grow more ill, they wonder what radioactive fallout looks like, with Jim noting, "I don't know, the government directive fails to mention how the populace can recognize it". Jim continues to speculate non-stop about the war and the bombing, while ignoring realities such as Hilda's bleeding gums ("must be ill-fitting dentures"), and insisting that their son must be $\mathrm{OK}$, as he had given him the government leaflet. Only in the final moments, when Hilda suggests that they pray, does recognition set in. Jim tries to recall 
Psalm 23, and they share a moment of comfort before light overtakes them. His struggle to recite this well-known verse suggests that religion had not played a significant role in his comfortable, yet mundane, middle-class life. When the Wind Blows portrays not only the failure of authorities to effectively respond to nuclear disaster, but also the danger of a narrow, disengaged world view. Ultimately, the instructions that Jim was so diligent in following failed them. David Bowie's title song for the film includes the lyrics, "So long child, I'm on my way, and after all is done; So long child, it's all for naught, I dread to think of when the wind blows".

The protagonists in Testament and When the Wind Blows are frozen in a limited set of actions when faced with radioactive fallout. In Testament, this involves continuing daily activities while engaging in mutual aid within the community. The bomb appears with no warning or context. In When the Wind Blows, Jim and Hilda filter their experiences and expectations through earlier experiences of war, and the news program builds anticipation for an expected bombing. While Jim dutifully follows government instructions for building the shelter, in the aftermath of the bombing, he cannot comprehend their isolation. As radiation symptoms build, he makes excuses and waits for imminent rescue. While his imagination works overtime in romanticizing past British leaders and his own capacity to respond, he cannot process this new event. In these films, the confrontation with radiation is immediate, dire, and short-term.

\section{Open Care}

In contrast to the late Cold War visions of the short-term consequences of nuclear disaster presented in Testament and When the Wind Blows, artists Erich Berger and Mari Keto acknowledge that nuclear disaster and radioactive waste are part of the earth's long-term future. The past decade has seen the nuclear accident at the Fukushima Daiichi power plant in Japan and the development of permanent waste facilities such as the Onkalo Spent Nuclear Fuel Repository in Berger's native Finland. Berger and Keto's work recognizes that humans and non-humans are already living with nuclear disaster, and that immediate gains for nuclear power are tempered by long-term debts paid out against the future.

In Open Care, Berger and Keto imagine a system for individuals to confront and manage the hazards of radioactive waste over the span of generations. Berger, a Helsinki-based artist and curator who explores the materiality of information, is the director of Bioartsociety, an organization bridging the arts and natural sciences. ${ }^{1}$ Keto, a Copenhagen-based artist with art degrees in precious metals and blacksmithing, merges her craftmanship with a research-based conceptual approach. ${ }^{2}$ The Open Care installation was part of the annual Open Fields, RIXC Art Science Festival in Riga, and was displayed at the National Library of Latvia in 2016.

Through science-based speculative fiction, Open Care proposes to address the following "social thought experiment: what if nuclear waste were a very personal responsibility and thus part of our everyday life and our cities?" (See Note 1) Through the imagined establishment of the "Open Care Foundation," Berger and Keto envisioned a system for distributing nuclear waste storage "which implicates us intimately in a much longer swath of the future than most of us imagine easily". The Foundation is envisioned as a multigenerational organization serving as the "administering body" for the public distribution of nuclear waste storage. ${ }^{3}$

In the system, a series of ninety-five steel pellets encase the toxic waste, labeled Americum 241, and are mounted on a bronze disk with a stand. An invented monitoring system includes an electroscope, gold leaf, and fur to charge an electrostatic charger. The electroscope, an early instrument used to detect an electric charge or ionizing radiation, operates by attaching gold leaves to an electrical conductor, which exits an insulated container. In Berger and Keto's iteration, their electroscope is intended to test the levels of remaining radioactivity in the pellets. The gold leaf electroscope contains a baseplate, an ionization chamber with a deflective mirror, and a measuring rod with an amber isolator. ${ }^{4}$ 
An electrostatic charger, comprised of an acrylic rod and a fur pelt, serves to activate the electroscope. Other accessories include five spare gold leaves, and a sand timer, tilted on its side. The accompanying spiral-bound "Open Care Foundation Handbook" provides instructions for monitoring the pellets at set intervals. The instructions are intended to be passed down over generations to determine whether their waste is still toxic. Once the waste reaches stabilization, the care for the disk is completed, and the handbook recommends contacting the nearest "Open Care Facility, if still existing". The guidelines conclude, "If the language of the handbook becomes difficult to understand, obtain an update or update it yourself". ${ }^{5}$ Through their invented system, Berger and Keto break down the extended and difficult-to-imagine timescale of radioactive decay, making it possible to assess and comprehend. Notably, while the "foundation" provides the guidelines, the artists place the ownership of radioactive waste on individuals, as a personal responsibility to manage and care for. If the waste outlasts supporting facilities, or even the language used, it is left to the caregiver to determine the next steps.

The installation creates a long-term narrative for nuclear waste storage that is both speculative and scientifically grounded. Berger explains, "In the installation this story is materially enacted by displaying the nuclear waste, the instruments and the handbook. The whole set is fully functional, and the story could start at any moment in time" (see Note 3). While addressing the immense scope and scale of nuclear waste is beyond the capability of any single individual, Berger and Keto help to visualize the shared personal responsibility of passing toxic waste to future generations.

While the procedures outlined for caring for the waste exist in a secular, humancentered realm, the handbook refers to the installation as "shrine", associating the instruments on display with sacred relics, deserving of veneration. Through this display choice, the instruments are assigned elevated value. Further, the prescribed rituals for caring for the nuclear waste are imbued with reverence and require a collective response. In such a system, the awe-provoking nature of atomic power can be seen to take the place of the supernatural forces at the heart of traditional religious systems.

Open Care developed from Berger and Keto's Inheritance project, which contrasts the immediate gains of nuclear power versus the deep future impacts of toxic waste. In Inheritance, part of the 2016 exhibit Perpetual Uncertainty: Contemporary Art in the Nuclear Anthropocene at Umeå University's Bildmuseet in Sweden, a set of jewelry made of both precious metals and radioactive thorianite and uraninite, that are unwearable until, far in the future, they stabilize into non-radioactive lead (Regine 2016). The Open Care display includes an auto-radiography, "image produced when the radioactive energy emitted by an object takes a photo of the object itself", of a necklace from Inheritance (Regine 2016). Through such work, Berger and Keto question, "What do we leave behind, what will the future inherit from us? How can we as individuals and society deal with the scales and scopes of deep time? How can we make sense of the vast timescales involved?" (See Note 1) Berger points out that by burying nuclear waste, it does not disappear, but creates a debt that will be "sent into a future of humans and non-humans which we do not know and a future we will not be part of anymore" (see Note 3). Ultimately, both Open Care and Inheritance cast our attention far beyond the immediate benefits of nuclear power, providing ways to visualize and take personal responsibility for difficult-to-comprehend nuclear processes.

\section{Conclusions}

The films and artworks highlighted in this paper suggest several methods of "maintenance" following nuclear disaster - the preservation of family, the building of a shelter, and the invention of a long-term nuclear waste-disposal solution. In both Testament and When the Wind Blows, the immediate, devastating conditions of nuclear attack and radiation poisoning render such efforts futile. While Carole Wetherly had no preparation for the attack and struggles to take any action afterward, Jim feels convinced that he and Hilda will prevail if only he follows public directives. Religious faith is represented in both films 
but does not structure meanings for the film's protagonists. Rather than providing any justifications or hopes for redemption, the films portray religion as a means for finding human comfort in an unescapable situation. Religious faith cannot address or resolve the disaster that has occurred. In Testament, the presence of the priest reflects the growing hopelessness of the doomed community. While the sacred nature of religion sets it apart from other forms of authority, during community gatherings, Hollis joins secular leaders of government, law, and education, all of whom are unable to alter their situation. While Hollis loses his faith, he still shows compassion in providing material aid and human comfort to those who have lost loved ones. In When the Wind Blows, prayer is turned to as a last resort, after all "practical" preparations have failed. However, given Jim's detachment from religion, this effort can be read as an act of comfort, rather than one of faith. Both films break from both traditional religious apocalyptic narratives which feature divine judgement, as well as more typical secular apocalyptic narratives, which usually suggest the possibility of meaning and survival.

The contemporary Open Care, in contrast, moves beyond the immediacy of a nuclear attack, and addresses the already-present crisis of radioactive waste as a global concern. Through a series of tools, displayed as if part of a shrine, Open Care functions to give structure and form to the ongoing problem of radioactive waste. While religion does not play an overt role in this system, the shrine-like quality of the display suggests that in facing $21^{\text {st }}$-century nuclear threats, human actions should be centered and venerated. In contrast to Littman and Murakami's narrative films, Berger and Keto's art installation offers a more open-ended, forward-looking response for taking pre-emptive and long-term action. Through the arc of narrative film and installation art examined in this article, the dire consequences of inaction and detachment give way to new systems of humanistic care, based in shared responsibility, that are necessary for facing the nuclear future.

Funding: This research received no external funding.

Institutional Review Board Statement: Not Applicable.

Informed Consent Statement: Not Applicable.

Data Availability Statement: Not Applicable.

Conflicts of Interest: The author declares no conflict of interest.

\section{Notes}

Inheritance Project: Contact. http://inheritance-project.net/index.php/contact/, accessed on 30 October 2021.

About Mari Keto. http://mariketo.com/about/, accessed on 30 October 2021.

E-mail correspondence with Erich Berger, 12 November 2021.

Open Care Foundation Handbook, from Open Fields Exhibition, National Library Riga Latvia, p. 23.

Open Care Foundation Handbook, from Open Fields Exhibition, National Library Riga Latvia, p. 22.

\section{References}

Amen, Carol. 1981. The Last Testament. Ms. Magazine. August, pp. 72-74, 82-86. Available online: https://media.oiipdf.com/pdf/f6 2b551a-7915-4057-aae5-6cfbf8217152.pdf (accessed on 13 November 2021).

Boyer, Paul. 1985. By the Bomb's Early Light: American Thought and Culture at the Dawn of the Atomic Age. Chapel Hill: University of North Carolina Press.

Evans, Joyce. 1998. Celluloid Mushroom Clouds. Boulder: Westview Press.

McCrillis, Neal R. 2002. Atomic Anxiety in Cold War Britain: Science, Sin, and Uncertainty in Nuclear Monster Films. In Screening Scripture: Intertextual Connections Between Scripture and Film. Edited by George Aichele and Richard Walsh. Harrisburg: Trinity Press International.

Nitzke, Solvejg. 2016. Fictional Shelters and Shelter Fiction. In The Apocalypse in Film: Dystopias, Disasters, and Other Visions about the End of the World. Edited by Karen A. Ritzenhoff and Angela Krewani. Lanham: Rowman \& Littlefield.

Ostwalt, Conrad. 2009. Apocalyptic. In The Routledge Companion to Religion and Film. Edited by John Lyden. London and New York: Routledge. 
Regine. 2016. Inheritance, A Precious Heirloom Made of Gold and Radioactive Stones. We Make Money Not Art. November 7. Available online: https:/ / we-make-money-not-art.com/inheritance-a-precious-heirloom-made-of-gold-and-radioactive-stones / (accessed on 13 November 2021).

Ritzenhoff, Karen A., and Angela Krewani. 2016. Introduction. In The Apocalypse in Film: Dystopias, Disasters, and Other Visions about the End of the World. Edited by Karen A. Ritzenhoff and Angela Krewani. Lanham: Rowman \& Littlefield.

Shapiro, Jerome. 2001. Atomic Bomb Cinema: The Apocalyptic Imagination on Film. New York: Routledge.

Sturken, Marita. 2007. Tourists of History: Memory, Kitsch, and Consumerism from Oklahoma City to Ground Zero. Durham: Duke University Press.

Weart, Spencer. 2012. The Rise of Nuclear Fear. Cambridge: Harvard University Press. 